\title{
Teacher Certification Policy On State Elementary Schools
}

\section{Fahrurroji Sidik*) and Widayati**)}

*) Student of Master of Law, Faculty of Law, Sultan Agung Islamic University, email: fahrurrojisidik@gmail.com

${ }^{* *}$ ) Faculty of Law Universitas Islam Sultan Agung

\begin{abstract}
The purpose of this study was to determine how the teacher certification policy implementation process and how the certification affects the professionalism of teachers at Wanoja 01 Elementary School and to find out what are the constraints or inhibiting factors in the certification policy. This study uses a sociological juridical approach that uses descriptive research with a qualitative approach with the technique of determining informants using purposive techniques and is developed through the snowball technique. The results of this study indicate that the implementation of the teacher certification policy at Wanoja 01 Elementary School, Salem Sub-District is good and fulfills the six variables of the implementation of public policy models of Van Meter and Van Horn. Certification has a positive role in the level of professionalism of teachers at Wanoja 01 Elementary School, Salem SubDistrict. From the results of its implementation, there are several obstacles or obstacles faced. Such as the delay in disbursing the teacher professional allowance and the effect of teacher certification that has not shown significant results for teacher effectiveness in improving quality and quality.
\end{abstract}

Keywords: Teacher Certification; Policy; Elementary School.

\section{Introduction}

The quality of education in Indonesia at this time cannot be said to be good and quality, because when compared to neighboring countries that have slowly but surely left Indonesia in the quality of education of a nation. A simple example is a neighboring country, namely Malaysia, which used to import a lot of educators from Indonesia but now is able to independently implement quality education for its citizens.

In this regard, the government has enacted Act No. 14 of 2005 concerning Teachers and Lecturers. In Chapter 1, article 1 paragraph (1) UUGD defines teachers as professional educators with the main task of educating, teaching, guiding, directing, training, assessing and evaluating students in early childhood education through formal education, basic education, and secondary education.

Teachers are professional educators who have important duties, functions and roles in educating the nation's life. ${ }^{1}$ Article 31 paragraph (1) of the 1945 Constitution states that every citizen has the right to receive education and paragraph (3) stipulates that the government endeavors and implements a national education system, which increases faith and piety and noble character in the framework of the intellectual life of the nation, which is regulated by law.

\footnotetext{
${ }^{1}$ Dermawati, Penilaian Angka Kredit Guru, Jakarta: PT Bumi Aksara, 2013, p.1
} 
Formally the teacher certification policy is regulated in the Law of the Republic of Indonesia No. 20 of 2003 concerning the National Education System, Law on Teachers and Lecturers No. 14 of 2005, Government Regulation no. 32 of 2013 concerning Amendments to Government Regulation Number 19 of 2005 concerning National Education Standards, Government Regulation No. 19 of 2017 concerning Amendments to Government Regulation No. 74 of 2008 concerning Teachers, Regulation of the Minister of Education and Culture No. 16 of 2007 concerning Teacher Qualifications and Competencies, Regulation of the Minister of Education and Culture Number 62 of 2013 concerning Teacher Certification in Position in the Context of Organizing and Equalizing Teachers, Regulation of the Minister of Education and Culture Number 29 of 2016 concerning Certification for Teachers Appointed Before 2016 and Permendikbud No. 37 of 2017 concerning InService Teacher Certification.

In Act No. 14 of 2005 article 1 point (11) explains that certification is the process of granting educator certificates to teachers and lecturers, article 2 states that the recognition of teachers as professional personnel is proven by teacher certification, article 11 explains that teacher certification is given to teachers that has met the requirements. Furthermore, Article 16 states that teachers who have teacher certificates receive a professional allowance of one salary, both public and private teachers are paid by the government.

From the quotation above, it can be understood that certification is the process of giving educator certificates to teachers who have met certain requirements, namely having academic qualifications, competence, being physically and mentally healthy, and having the ability to realize the goals of national education, coupled with an increase in proper welfare. ${ }^{2}$

Research on the implementation of teacher certification policies is focused on elementary school level education units (SD). The reason why the SD education unit was chosen is not only to focus, but also because elementary schools are the fundamental basis of an educational process at an early stage so that the portrait of teachers in primary schools will determine the abilities of students which will then determine the educational process at a later stage. According to Nurdin Usman, implementation or implementation boils down to activity, action, action, or the existence of a mechanism or system. Implementation is not just an activity, but an activity that is planned and to achieve the objectives of the activity. ${ }^{3}$

This study aims to determine how the implementation of the Wanoja 01 Public Primary School teacher certification policy, the impact of teacher certification on the professionalism of Wanoja 01 Public Elementary School teachers and the factors that hinder the implementation of teacher certification.

\section{Research Methods}

The research method used is a sociological juridical approach, namely identifying and conceptualizing law as a real and functional social institution in a real life system. This type of research uses descriptive research which is a research

\footnotetext{
2 Masnur Muslich, Sertifikasi Guru Menuju Profesionalisme Pendidik, Jakarta: Bumi Aksara, 2007, p.2 ${ }^{3}$ Nurdin Usman, 2002, Konteks Implementasi Berbasis Kurikulum, Bandung: CV. Sinar Baru, p.70
} 
procedure that produces descriptive data in the form of written and spoken words from people and observable behavior. ${ }^{4}$

Types and sources of research data include primary data and secondary data. Primary data is data that is obtained directly from the object. ${ }^{5}$ Primary data obtained by field studies (field research) with interviews consisting of. Secondary data from primary legal materials in this study are secondary legal materials; (a) Text books and scientific writings relating to the problem under study, and (b) Official documents or archives or archives relating to Teacher certification in Salem Sub-District, Brebes.

The next technique is observation, by directly observing the implementation of the teacher certification program for Wanoja 01 Elementary School, Salem Sub-District, Brebes Regency or especially in the Education, Youth and Sports Office of Brebes Regency and UPT Dindikpora, Salem Sub-District.

\section{Results And Discussion}

Teacher certification is a program designed to see the eligibility of teachers in acting as learning agents that can realize national education. ${ }^{6}$ Certification is the process of giving educator certificates to teachers who have met certain requirements, namely having academic qualifications, competence, being physically and mentally healthy, and having the ability to realize the goals of national education, coupled with an increase in proper welfare. ${ }^{7}$

The term certification can also be interpreted as a certificate (certificate) from the competent authority given to profession, and at the same time as a statement (license) on the suitability of the profession to carry out tasks. ${ }^{8}$ Therefore, in this study, teacher certification standards and policies refer to and are based on Act No. 14 of 2005 concerning Teachers and Lecturers which explains that teachers are required to be certified and the measure of teacher professionalism is proven by the existence of an educator certificate in accordance with the subjects mastered and carried out by the teachers as a manifestation of the implementation of teacher certification, which is a sign of having met the professional standards of teachers to realize the goals of national education. ${ }^{9}$

This was explained by Mr. Darmasyah as the Head of the Basic Education PTK Section in the Field of Education, Youth and Sports Affairs in his interview which explained that the Teacher and Lecturer law is a legal basis which explains that teachers are required to have an educator certificate by joining the teacher certification program. The purpose of certification itself is clear to improve teacher competence. In addition to getting a certificate, with certification teachers also get allowances which of course can help improve the welfare of teachers. Therefore,

\footnotetext{
${ }^{4}$ Lexy J. Moleong, 2010, Metodologi Penelitian Kualitatif, Bandung: PT. Remaja Rosdakarya, p. 4

5 J. Supranto, 2003, Metode Penelitian Hukum dan Statistik, PT Rineka Cipta, Jakarta, p. 2

${ }^{6}$ Bedjo Sujanto, 2009, Cara Efektif Menuju Sertifikasi Guru, Jakarta: Raih Asa Sukses, p.7

${ }^{7}$ E. Mulyasa, 2009, Praktik Penelitian Tindakan Kelas, Bandung: PT. Remaja Rosdakary, p. 34

8 Imam Wahyudi, 2012, Panduan Lengkap Uji Sertifikasi Guru, Jakarta: Prestasi Pustaka Raya, p. 68

9 Solichin Abdul Wahab, 1997, Analisis Kebijakan : Dari Formulasi ke Implementasi Kebijaksanaan Negara, Jakarta: Bumi Aksara, p.2
} 
with this allowance, it is hoped that teachers will be more enthusiastic at work and have a sense of responsibility to create a quality teaching and learning process. ${ }^{10}$

The teachers of Wanoja 01 Elementary School as the target of this policy understand and know what are the standards of the teacher certification policy, because of course the teachers as the target of this policy must follow all the requirements set by the government in order to achieve the objectives of the policy. ${ }^{11}$ This is evidenced by teachers' understanding of the teacher certification policy, where most teachers say that certification is the process by which a teacher gets an educator certificate. Teachers who have a certificate or certification will be said to be professional teachers, which means that the teacher is competent in their respective fields of expertise. ${ }^{12}$ Where in addition to improving the quality of education, teacher certification is also seen as a form of improving the welfare of teachers provided by the government.

In addition, the Wanoja 01 Elementary School teacher is part of the policy target about Teacher certification requirements, states that the existing requirements start from teachers who are allowed to take certification are teachers who have become teacher educators as of December 31, 2015 where the teacher must qualify for S-1 or equivalent to D-IV. Then the teacher must also have 24 hours of teaching hours, and have a minimum work period of 5 years. In addition, to get the teacher professional allowance, schools must provide a report every three months containing: (1) An official report on the verification of the teacher professional allowance file signed by the supervisor. (2) Teacher data (3) List of proposed recipients of the teacher professional allowance (4) Attendance list (5) Decree on the division of teacher duties in the teaching and learning process (6) SK Division of teacher duties in guiding extra-curricular activities (7) Schedule of lessons,

Table 1.The condition of Public Elementary School Teachers in Salem SubDistrict who have and have not followed functional position certification

\begin{tabular}{|c|c|c|c|c|c|c|}
\hline \multirow[t]{2}{*}{ No. } & \multirow[t]{2}{*}{ School Level } & \multicolumn{2}{|c|}{ Gender } & \multirow{2}{*}{$\begin{array}{c}\text { Total } \\
\text { number of } \\
\text { teachers }\end{array}$} & \multicolumn{2}{|c|}{$\begin{array}{c}\text { Attending } \\
\text { Certification }\end{array}$} \\
\hline & & Male & Female & & Already & Not yet \\
\hline 1. & $\begin{array}{c}\text { Primary } \\
\text { school }\end{array}$ & 158 & 104 & 262 & 243 & 19 \\
\hline
\end{tabular}

Source: Data from the Brebes District Education Office

Regarding human resources in the teacher certification policy, the number of civil servant teachers at Public Elementary Schools in Salem Sub-District based on data from the UPT Education Office, Salem Sub-District, Brebes Regency, is 262 people. Starting from 2007 to 2018, there have been 243 teachers who have received teacher certificates or certificates, meaning that only 19 teachers have not

\footnotetext{
${ }^{10}$ Results of Interview with Mr. Darmasyah as Head of Section of Basic Education PTK in the Field of Public Development of the Education, Youth and Sports Office on Thursday, December 272018 at 08.40 WIB.

11 Arif Rohman \& Teguh Wiyono, 2010, Education Policy in Decentralization Era, Yogyakarta: Pustaka Pelajar, p.2

12 Budi Winarno, 2002, Teori dan Proses Kebijakan Publik, Yogyakarta: Media Pressindo. p.15
} 
been certified. This means that $92.75 \%$ of public elementary school teachers in Salem Sub-District have been certified and the remaining $7.25 \%$ are not. (see table 1).

Table 2. Status of Public SD Teachers in Wanoja 01 who have and have not followed functional position certification

\begin{tabular}{ccccccc}
\hline No. & School Level & \multicolumn{2}{c}{ Gender } & \multirow{2}{*}{$\begin{array}{c}\text { Total } \\
\text { number }\end{array}$} & \multicolumn{2}{c}{$\begin{array}{c}\text { Attending } \\
\text { Certification }\end{array}$} \\
\cline { 3 - 4 } \cline { 5 - 7 } & Male & Female & $\begin{array}{c}\text { of } \\
\text { teachers }\end{array}$ & Already & Not yet \\
\hline 1. & SD Wanoja 01 & 3 & 2 & 5 & 4 & 1 \\
\hline
\end{tabular}

Source: Wanoja Public Elementary School 01

Meanwhile, the total number of teachers at Wanoja 01 Elementary School in the $2017 / 2018$ school year is 10 people, consisting of 6 people with civil servant status and 4 non-permanent (honorary) teachers. Of the 6 teachers who are civil servants, 5 of them already have an educator certificate or have already been certified and 1 teacher is a civil servant who has not received certification.

The teachers of Wanoja 01 Elementary School according to their education level are as follows:

\begin{tabular}{clcl}
\hline No. & \multicolumn{1}{c}{ Name } & Gender & \multicolumn{1}{c}{ Educational stage } \\
\hline 1. & Siswanto, S.Pd & $\mathrm{M}$ & S-1 Geography \\
\hline 2. & Siti Arpaeni, S.Pd.SD & $\mathrm{F}$ & S-1 PGSD \\
\hline 3. & Kusro, S.Pd & $\mathrm{M}$ & S-1 Biology \\
\hline 4. & Rohamah, S.Pd.SD & $\mathrm{F}$ & S-1 PGSD \\
\hline 5. & Edi Riyanto, S.Pd.SD & $\mathrm{M}$ & S-1 PGSD \\
\hline 6. & Murshidin & $\mathrm{M}$ & SGO \\
\hline 7. & Rodiah, S.Pd.SD & $\mathrm{F}$ & S-1 PGSD \\
\hline 8. & Oco Irawan, S.Pd.SD & $\mathrm{M}$ & S-1 PGSD \\
\hline 9. & Nia Nurdiati, S.Pd.SD & $\mathrm{F}$ & S-1 PGSD \\
\hline 10. & Samsul Aripin, S.Pd & $\mathrm{M}$ & S-1 PAI \\
\hline \multicolumn{4}{l}{ Source: Wanoja Public Elementary School 01} \\
\end{tabular}

Furthermore, the teacher classification of Wanoja 01 Elementary School according to education level and rank is as follows:

\begin{tabular}{lll}
\hline Description & \multicolumn{1}{l}{ total } \\
\hline Qualification According to & \\
Education: & 1 \\
1. Senior high school & - \\
equivalent & 9 \\
2. D-III & - \\
3. S-1 & 1 \\
4. S-2 & & 1 \\
Qualification & According to & 4 \\
Group: & &
\end{tabular}




\begin{aligned} & 1. Group II \\ & 2. Group III \\ & 3. Group IV \\ & \hline Total $\mathbf{1 0}$ people \\ & \hline\end{aligned}

Source: Wanoja Public Elementary School 01

Based on the results of research from informants, the path followed in the 2017 certification registration process is the PLPG path. This was emphasized by Mr. Edi, a teacher at Wanoja 01 Elementary School in his interview who explained that the implementation of certification has several paths, but he follows the PLPG certification path due to adjusting the path opened by the government. Teachers who have passed the certification will do their best to improve performance and devote themselves to the smooth running of education. However, it depends on each individual.

Teachers at Wanoja 01 Elementary School seem very enthusiastic in improving their performance, because teachers are very aware of the importance of improving the quality of education according to their expertise even though it all depends on each individual. However, teachers have realized that with the existence of a certification policy, of course the teachers must also be in line with the government's goal of increasing teacher competence and the quality of education in order to realize quality education. ${ }^{13}$ This was emphasized by Mr. Edi, a teacher at Wanoja 01 Elementary School in his interview, which explained that he always tried to improve his performance, especially for Wanoja 01 Elementary School students.

In connection with the relationship between organizations in implementing the teacher certification policy at Wanoja 01 Public Elementary School, the Principal of Wanoja 01 Elementary School always coordinates and collaborates with the UPT Education Office and also the Education Office of Brebes Regency and other parties related to implementing the teacher certification policy. This was emphasized by Mr. Siswanto, the Principal of Wanoja 01 Elementary School in his interview which explained that the parties involved in teacher certification were the school, UPT District Education Office and District Education Office. Teacher certification assessments are carried out by a certification team appointed by the government. For relations between parties involved in certification, coordination and cooperation are good and are in accordance with existing regulations.

Based on the results of the informants' information, the teachers have received socialization related to teacher certification for the PLPG (Teacher Professional Education and Training) path. This is because the PLPG pathway requires teachers to take part in education and training as a mechanism for registering using this route, so that some teachers think that socialization is done but only for teachers who register through the PLPG route.

Based on the socialization that has been carried out, we can see that the policy makers at the center have created a good communication system with a two-way communication system. Then, teachers who used to have difficulty obtaining information are now facilitated by information that can be viewed via

${ }^{13}$ AG. Subarsono, 2015, Analisis Kebijakan Publik, VII th Printing, Yogyakarta: Pustaka Pelajar, p. 2 
the internet because teacher data has been integrated online with the Central Education Office.

Based on Mr. Edi, a teacher at Wanoja 01 Elementary School, for services related to certification itself, it has been carried out openly to teachers who have problems related to certification, all teachers can convey the constraints or problems they face and are directly responded to by the staff of the Brebes Regency Education Office.

In this study, based on the information of Mr. Edi as a teacher at Wanoja 01 Elementary School, the researcher also saw that there were problems faced related to the implementation of this teacher certification. Apart from the insufficient number of teaching hours and incorrect data input. Mr. Edi also explained that in this certification the procedures were convoluted and the requirements were too many, for example, the government had previously made regulations to use a paperless system but currently it has not been implemented properly because teachers are still doing filing even though it has been updated. in the existing application until the files that are collected are piled up so that according to some teachers this affects the main objective of the certification program.

In research that has been conducted by researchers, there are several obstacles in implementing teacher certification, including frequent errors in inputting data by respective school operators and the lack of information for areas that are still difficult to reach by the internet. The Professional Allowance for Teachers also experienced delays because the District Education Office of Brebes handled all teachers in Brebes Regency so that it was possible for errors from the employees who entered the teacher's data and the facilities used also decreased their performance.

In addition, employees must also verify and validate the documents of teachers who have passed certification. Submission of this file is on schedule but the Brebes District Education Office takes a long time to process it because employees have to input the teacher's account number data in the form of a table so that employees must be careful in inputting data because the table is not in soft copy form. Therefore, this may create delays for teachers in receiving their Professional Allowance.

From a social perspective, there are obstacles faced by teachers regarding this teacher certification policy. The first is the process of meeting existing requirements, as well as delays in receiving professional teacher allowances. Then the second is the complicated procedure and the many requirements. where with the many requirements used to make teachers too busy to meet these requirements than teaching students. Another thing is when the government previously made regulations to use the paperless system but at this time it has not been implemented properly because if seen at this time teachers are still doing filing even though it has been updated in the available teacher application. 


\section{Closing}

\subsection{Conclusion}

a. The implementation of teacher certification policies can be seen from several implementation variables, namely policy standards and objectives, resources, relationships between organizations, characteristics of implementing agents, economic, social and political conditions as well as implement dispositions. Level of teacher professionalism can be categorized as quite good. Certification has a positive effect on improving teacher professionalism in teaching in schools, where the implementation of certification has brought progress and improvements to the quality of teachers in teaching and learning activities at Wanoja 01 Public Elementary School.

b. In the implementation of the teacher certification policy, there are several main obstacles or obstacles, namely there are still frequent delays in the disbursement of teacher professional allowance funds and the ineffective teacher certification policy to significantly improve the quality of a teacher so that it can be said that this policy has not been implemented properly.

\subsection{Suggestion}

a. With regard to the relationship between organizations, cooperation and coordination between implementing agencies between the Regional Asset Management and Financial Management Agency of the Brebes Regency Government and the Brebes Regency Education Office should be further improved so that delays in disbursing the professional teacher allowances can be overcome. The characteristics of the implementing agency, civil servants at the Brebes District Education Office who handle teacher certification policies, especially in the field of Basic Education CAR, should be increased in number so that they are not overwhelmed in serving all teachers in Brebes Regency.

b. In connection with economic, social and political conditions, the government should have a high commitment in distributing teacher professional allowances and teachers who have received the professional allowance for teachers at Wanoja 01 Elementary School should use these funds as well as possible to increase educational needs so that teacher realization the professional can be realized. Disposition of the implementation, the Brebes District Education Office and the principal are expected to pay more attention to teachers by providing motivation and encouragement through coaching, especially in the learning process in the classroom, so that the quality of education can increase.

\section{References}

Agustino L, 2008, Dasar-Dasar Kebijakan Publik, Bandung: Alfabeta.

Dermawati, 2013, Penilaian Angka Kredit Guru, Jakarta: PT Bumi Aksara.

Indiahono D, 2009, Kebijakan Publik Berbasis Dynamic Policy Analysis. Yogyakarta: Gava Media. 
Joko Widodo, 2007, Analisis Kebijakan Publik : Konsep dan Aplikasi Analisis Proses Kebijakan Publik, Bayumedia Publishing.

Moleong LJ, 2010, Metodologi Penelitian Kualitatif, Bandung: PT. Remaja Rosdakarya.

Mulyasa E, 2009, Praktik Penelitian Tindakan Kelas, Bandung: PT. Remaja Rosdakarya.

Muslich M, 2007, Sertifikasi Guru Menuju Profesionalisme Pendidik, Jakarta: Bumi Aksara.

Subarsono, 2005, Analisis Kebijakan Publik. Konsep, Teori dan Aplikasi, First Printing, Yogyakarta: Pustaka Pelajar.

Sujanto Bedjo, 2009, Cara Efektif Menuju Sertifikasi Guru, Jakarta: Raih Asa Sukses.

Supranto J, 2003, Metode Penelitian Hukum dan Statistik, Jakarta: PT Rineka Cipta.

Usman N, 2002, Konteks Implementasi Berbasis Kurikulum, Bandung: CV. Sinar Baru.

Wahab SA, 1997, Analisis Kebijakan : Dari Formulasi ke Implementasi Kebijaksanaan Negara, Jakarta: Bumi Aksara

Wahyudi Imam, 2012, Panduan Lengkap Uji Sertifikasi Guru, Jakarta: Prestasi Pustaka Raya.

Winarno B, 2002, Teori dan Proses Kebijakan Publik, Yogyakarta: Media Pressindo.

Wiyono AR, 2010, Education Policy in Decentralization Era, Yogyakarta: Pustaka Pelajar. 